\title{
The impacts of climate change on tribal traditional foods
}

\author{
Kathy Lynn • John Daigle • Jennie Hoffman • \\ Frank Lake • Natalie Michelle • Darren Ranco • \\ Carson Viles • Garrit Voggesser • Paul Williams
}

Received: 15 November 2012 / Accepted: 4 March 2013 / Published online: 26 March 2013

(C) Springer Science+Business Media Dordrecht 2013

\begin{abstract}
American Indian and Alaska Native tribes are uniquely affected by climate change. Indigenous peoples have depended on a wide variety of native fungi, plant and animal species for food, medicine, ceremonies, community and economic health for countless generations. Climate change stands to impact the species and ecosystems that constitute
\end{abstract}

This article is part of a Special Issue on "Climate Change and Indigenous Peoples in the United States: Impacts, Experiences, and Actions” edited by Julie Koppel Maldonado, Rajul E. Pandya, and Benedict J. Colombi.

K. Lynn $(\bowtie)$

Adjunct Research Faculty, Environmental Studies Program, University of Oregon,

5223 University of Oregon, Eugene, OR 97403-5223, USA

e-mail: kathy@uoregon.edu

J. Daigle

School of Forest Resources, 221 Nutting Hall, University of Maine, Orono, ME 04469-5755, USA

J. Hoffman

EcoAdapt and Jennie Hoffman Research and Consulting, 4755 NE Lamms Lane, Poulsbo,

WA 98370, USA

e-mail: hoffrau@gmail.com

F. Lake

USDA Forest Service, Pacific Southwest Research Station, 3644 Avtech Parkway, Redding, CA 96002, USA e-mail: franklake@fs.fed.us

N. Michelle

Graduate Student, University of Maine, Orono, ME 04469, USA

D. Ranco

Department of Anthropology, University of Maine, 5773 S. Stevens Hall, Orono, ME 04469-5773, USA

C. Viles

Undergraduate Student, University of Oregon, 5223 University of Oregon, Eugene, OR 97403-5223, USA

G. Voggesser

Tribal Partnerships Program, National Wildlife Federation, 2995 Baseline Road, Suite 300, Boulder, CO 80302, USA

P. Williams

Suquamish Indian Tribe, PO Box 498, Suquamish, WA 98392, USA

e-mail: pwilliams@suquamish.nsn.us 
tribal traditional foods that are vital to tribal culture, economy and traditional ways of life. This paper examines the impacts of climate change on tribal traditional foods by providing cultural context for the importance of traditional foods to tribal culture, recognizing that tribal access to traditional food resources is strongly influenced by the legal and regulatory relationship with the federal government, and examining the multi-faceted relationship that tribes have with places, ecological processes and species. Tribal participation in local, regional and national climate change adaption strategies, with a focus on food-based resources, can inform and strengthen the ability of both tribes and other governmental resource managers to address and adapt to climate change impacts.

\section{Introduction}

American Indian and Alaska Native tribes face unique and disproportionate challenges from climate change that are not yet widely understood in academic or policy arenas. This paper explores one of these challenges in particular - the impact of climate change on traditional foods and the reality that 1) tribal access to resources is strongly influenced by the legal and regulatory relationship that tribes have with the federal government (Whyte 2013), and 2) tribes have a unique and multi-faceted relationship with places, ecological processes, and species. These frameworks shape tribal responses to climate change.

Indigenous peoples have depended on a wide variety of native fungi, plant and animal species for food, medicine, ceremonies, community and economic health for countless generations. Water is held sacred by many indigenous peoples (Cozzetto et al., submitted for this issue), and considered by some to be a traditional food (Jones et al. 2008; Colombi 2009). In combination with other stressors, climate change may affect tribes' relationships with traditional foods, including access, availability, harvesting strategies, and ability to store, process, and use foods in traditional ways.

The availability of all types of traditional foods (hunted, fished, gathered, and cultivated) has greatly diminished as ecosystems and water resources have been exploited or converted to other uses. The productivity of remaining ecosystems may be impacted by a variety of factors including disease, pollution, invasive species and management actions. Climate change can impact ecosystems and lifecycle processes in complex ways. For example, tribal harvesters have noticed shifts in harvest times for traditional foods; if the timing of flowering plants and the presence of pollinators, such as birds and insects, become less synchronized, impacts can ripple throughout the food webs.

The relationship between tribal culture and species, habitats, and ecosystems is integral to understanding the impacts of climate change on indigenous communities. Reciprocity - respect for and responsibility to-wildlife and natural resources is embedded in indigenous cultures. Reciprocal relationships are fundamental to how tribes will respond to climate impacts (Whyte 2013). The effects of climate change on traditional foods take place in the context of a host of other changes, both the ecological stressors commonly cited in climate change literature and the rapid cultural, economic, and political changes experienced by indigenous communities globally and by tribes in the United States since the arrival of Europeans (Parrotta and Agnoletti 2012). While this article focuses on indigenous peoples within the United States, these impacts are being experienced by indigenous peoples around the world (Maldonado et al. 2013).

This article seeks to illustrate some of the ways in which climate impacts on traditional foods may affect tribal cultures and traditional ways of life. To accomplish this, the article explores the cultural context for climate change impacts on traditional foods for Alaska Native and American Indian tribes, as well as the impacts of climate change on tribes' access 
to, use of, and relationship with traditional foods. The article also examines historical and contemporary examples of tribal adaptation that may inform strategies to address climate impacts on traditional foods in the future.

\section{Cultural context: understanding the impacts of climate change on traditional foods}

The indigenous relationship between food and people is intimately tied to the cultural, physical, emotional, psychological, and spiritual health of tribal communities. The impacts of climate change on particular species or ecological processes, therefore, are directly connected to climate impacts on tribal culture and the importance that traditional foods have for tribes. This section is intended to build an understanding of the impacts climate change may have on tribal culture. This is accomplished by describing indigenous relationships with traditional foods broadly, and providing an example of what traditional foods (e.g., berry plants) mean to the Wabanaki people as way of understanding the potential for climate change to affect tribal culture and traditional ways of life.

Tribes have long historical, cultural, and physical connections to plants and wildlife. These relationships manifest themselves in their connections to and reliance on traditional foods. These bonds form the basis of traditional ecological knowledge (TEK), the indigenous way of knowing (Williams and Hardison, submitted for this issue). TEK, established over countless generations of interactions with the natural world, provides a powerful roadmap to ensuring the sustainability of traditional foods. Simultaneously, TEK and tribal connection to traditional foods offer strategies for adaptation that can help tribal and non-tribal resource managers confront the climate challenge. As TEK informs research, tribes and non-tribal entities can work together to incorporate TEK in a tribally-appropriate manner (Williams and Hardison, submitted for this issue.)

Approximately 1.14 million ( $22 \%$ ) of American Indians and Alaska Natives live on or near reservations (Norris et al. 2012), and many pursue lifestyles with a mix of traditional subsistence and commercial harvesting activities . Traditional foods such as fish, game, nuts, fungi, berries, algae, greens, roots, water and seafood provide not only sustenance, but also cultural connections through storytelling, ceremonies, harvesting, processing, and sharing of food resources. Many tribes strive to maintain a strong, diversified traditional diet and foodrelated traditions, but are experiencing barriers such as poverty, and changes in ecosystem quality and species distribution instigated by pollution, urbanization, policy restrictions to traditional food access, cultural assimilation and climate change, (Jernigan et al. 2012; Kuhnlein and Receveur 1996; Norgaard 2005; Verbrugge 2010).

Climate change impacts on ecological processes, habitat quality, and species populations present a growing threat to traditional food use. Tribes are experiencing declines in health that accompany traditional food use declines. Obesity, diabetes and cancer, rare in communities living on a traditional diet, are now increasing health problems in tribes across the U.S. (Boyce et al. 1993; DeGonzague et al. 1999; Kuhnlein and Receveur 1996; Norgaard 2005; Ravussin et al. 1994; Teufel 1996; Kuhnlein et al. 2009). For example, the majority of Karuk people today, whose homeland stretches along the middle Klamath River in California, have experienced an almost complete elimination of two traditional staples from their historical daily diet: salmonids (Oncorhynchus sp.) and acorns (Notholithocarpus and Quercus sp.). These foods made up $50 \%$ of a traditional Karuk diet. Accompanying this loss are skyrocketing rates of diabetes $(21 \%$ of the population) and heart disease ( $40 \%$ of the population) (Norgaard 2005).

The loss of opportunity to gather traditional foods in tribal communities is resulting in the denial of their rights to have access to a steady supply of nutritionally balanced, culturally 
relevant foods (Conti 2006; Jernigan et al. 2012; Power 2008). Additionally, the preservation and maintenance of traditional knowledge and associated subsistence practices that accompany food acquisition are threatened. As traditional foods are affected by climate change through habitat alterations and changes in the abundance and distribution of species, there is a resulting erosion of traditional practices and knowledge (Kuhnlein and Receveur 1996; Nabhan 2010).

\subsection{Indigenous people, berry plants, and climate change}

To demonstrate a cultural context for considering climate impacts on traditional foods, we explore the multi-faceted relationship between berries and indigenous peoples in the Northeast. Traditional ecological knowledge about particular berry plant species encompasses the holistic aspects of wellness and includes physical, emotional, psychological and spiritual realms of the individual and community. These beliefs are reinforced by the traditional value systems of responsibility, respect, reciprocity, relationship, and reverence that are imbedded within many cultural customs and rituals. Despite the challenges of cultural loss, incomplete transmission of knowledge related to subsistence skills, and fewer opportunities for learning traditional lifeways from elders, many traditional practices are still employed in indigenous cultures. Today, as a result of economic conditions, subsistence practices and food acquisition are paramount for those who rely on hunting, fishing, trapping and berry harvesting.

Scientists have only begun to understand the importance of berry plants as food medicine in Native American cultures (Burns Kraft et al. 2008). Recent investigations have identified diverse phytochemicals in berries that act to prevent a wide range of metabolic syndromes and chronic disease outcomes (Seeram 2008). Current studies show significant improvement in cardiovascular protection and the biological parameters of metabolic syndromes, such as hyperglycemia, hyperlipidemia, hypertension and lipid peroxidation that are significant to native populations (Basu et al. 2010).

The common berry plants used by the Wabanaki people (the Penobscot, Passamaquoddy, Micmac, and Maliseet Indian Nations) include the familiar blackberries (Rubus allegheniensis \& R. canadensis), raspberries (Rubus occidentalis \& R. idaeus), blueberries (Vaccunuim angustifolium \& V. corymbosum), cranberries (Vaccinium macrocappon \& $V$. oxycoccos), and strawberries (Fragaria $x$ ananasa), as well as less familiar indigenous berries like shadberry (Amelanchier alnifolia), chokecherry (Prunus virginiana), high bush cranberry (Viburnum trilobum), elderberry (Sambucus nigra), and gooseberry (Ribes uvacrispa). Today, nutrition experts consider these berries "superfoods" based on their biochemical content and biological and physiological functions (Seeram 2008).

Wild berry plants serve a number of utilitarian, nutritional, medicinal, and spiritual purposes among the Wabanaki people. The berry fruits are not the only portion of the plant that is essential as food-medicine to the Wabanaki, for certain species the whole plant is utilized. The season, age of the plant (maturation stage), use (i.e. food or medicine), traditional teachings and ceremonies dictate which portion of the plant should be harvested, prepared, and administered.

Berries serve as key cultural indicators of ecosystem services in Wabanaki culture. The shadberry (or serviceberry) is a well-known commodity among the Wabanaki people. In early spring, the blossoming of the shadbush coincided with the arrival of the spring migration of the shad fish and acted as a signal for the people to move to the low lands (Frink and Dow 2005).

Berry plants are also extremely important for Wabanaki women. Recovery of the traditional uses of these plants has been on the rise in the younger generations of 
Wabanaki society over the past 20 years (Michelle 2012). The native women are returning to the traditional uses of berry plants for health, well-being, and spirituality. The strawberry represents a primary nutrient source for female reproductive development and the psychosocial behavior of the young adolescent female. The "Strawberry Ceremony" or "berry fast" is still used for female adolescents' initiation into womanhood. The traditional medicinal uses of berries and certain portions of the plant strengthen women's reproductive organs and act as the primary medicine for endocrine system balancing, reproductive toning, birthing preparation, post-partum bleeding and toning as well as a preventive for post-partum infections and uses during menopause (Cook 1996; Michelle 2012). Women also use berries for treating cyst formation in the reproductive organs. The Wabanaki continue to use sweet berries such as strawberries, raspberries, and blueberries to express love for each other and their children and these berries are often shared among the clans for use during sacred rituals.

Climate and other environmental changes are starting to affect the range, quality, and quantity of Wabanaki berry resources (Michelle 2012), as well as having impacts on these resources in other places such as Alaska (Kellogg et al. 2010). Wabanaki Nations in Maine and Canada are struggling to protect and preserve living cultural resources, such as berries. Pre-existing stressors, including dwindling territory, pollution, declining health services and ongoing assimilation policies are affecting access to and availability of cultural species, such as berries. As climate change adds to the impacts on berry plant use and access, tribal health and well-being will be under even greater threat.

\section{Climate impacts on traditional foods}

Native species and indigenous peoples' use of them are attuned to particular climates and ecosystems. Climate change will affect these balances, throwing ecosystems and traditional foods into disarray. Climate-related changes can exacerbate the impacts of existing stressors or conditions on species and ecosystems. These impacts to individuals, populations, and habitat quality will result in reverberating changes in food webs and the valued food species tribes utilize. This section explores a range of climate-related impacts on traditional foods, as well as discussion about the related impacts to tribal culture and traditional ways of life.

In the Pacific West, Columbia Plateau climate change threatens a multitude of ecosystems that provide traditional foods for tribal communities. Wild food resources such as huckleberries, are valued by many groups, and are addressed by broad scale climate adaptation strategies. However, these strategies may not consider many tribal traditional foods. Non-forested environments deemed "unproductive" by non-indigenous cultures often contain important tribal traditional foods. Such tribally valued bulbs and roots include: onions (Allium sp.), camas (Camassia sp.), brodiaea (Brodiea sp., Dichelostemma, Triteleia sp.), lilies (Lilium sp., Calochortus sp.), and lomatiums (Lomatium sp.) (Hunn 1990). Tribal efforts to amplify attention to these foods are increasing public and land manager cooperation in planning to preserve and restore components of these landscapes. In coastal Louisiana, tribes are beginning to see declines in traditional food resources as a result of land loss, saltwater intrusion and disruption of estuaries from increased storm activity (PNW TCCP 2012). Athabascan peoples in central Alaska are experiencing changes in moose habitat. Moose are an important staple food and the decline in moose has put stress on peoples' traditional diets. In addition to changes in where moose range, hunters have noticed that moose seem to appear less healthy (Daigle and Putnam 2009). Winter sea ice area is diminishing rapidly due to climate change, and the loss of this habitat is hurting Pacific walrus populations, which directly threatens Alaskan traditional food security (Verbrugge 2010; IPCC 2007a; NRC 2010a). 
Climate change impacts on water temperature and availability (see Cozzetto et al., submitted for this issue) will also have significant impacts on tribal traditional foods. Already, the lack of water is among one of the leading causes for the decline in the ability to grow corn and other crops (Lobell et al. 2008; NRC 2010a; Redsteer et al. 2010). Corn has been central to many native cultures, particularly Puebloan people in the Southwest and the use of corn pollen is central to every Navajo ceremony. In the Great Lakes region, warming winters and changes in water level are crippling the ability of wild rice to grow and thrive in its traditional range. Wild rice is a pillar of cultural health for the Anishnaabeg people, and any decline in wild rice negatively affects their well-being (Minnesota 2008). In response to threats facing wild rice, the Fond du Lac Band of Lake Superior Tribe has begun trying to address potential hydrological changes. In the early 1900s, settlers built ditches to drain the land for agricultural purposes, resulting in negative impacts to the watershed. The Fond du Lac are now building dams at ditch flow points to keep water levels stable and prevent extreme changes in water level that would negatively affect wild rice harvests (Hoene 2010).

Climate change is thought to be posing significant threats to salmon (Mote et al. 2003, Dittmer 2013; Grah and Beaulieu 2013; Beechie et al. 2012). Salmon is central to the lives of many indigenous peoples, providing spiritual, physical and cultural well-being (Dittmer 2013). Over the past two centuries, overharvest, habitat degradation, urbanization, and water diversion for a variety of human uses have led to dramatic declines in salmon populations (Mote et al. 2003), with profound effects on the peoples whose lives and cultures are intertwined with them. For some tribes, the loss was rapid and absolute: in the last few years, the Colville Tribes lost access to both salmon and their traditional fishing grounds following the construction of the Grand Coulee Dam on the Columbia River and the filling of the reservoir behind it (McKay and Renk 2002). Now, the rapidity of climate change may be exacerbating existing stressors and creating new ones, including extremes in stream flows and water temperatures that limit the survival of salmon fry (Mantua et al. 2010).

Already, projections indicate that salmon populations throughout the Puget Sound, in the Pacific Northwest, are expected to decline considerably as water temperatures warm (CPR 2011). The changing climate can also broaden the geographic range of disease organisms, increasing threats to salmon and other species. In Alaska, the Yukon River and its tributaries, for example, Chinook salmon are now commonly infected with a single-celled parasite previously unknown in Alaskan salmon (Kocan et al. 2004). Articles in this issue explore the impacts of climate change on salmon and tribal culture in greater detail (Dittmer 2013; Grah and Beaulieu 2013).

Shellfish have been an integral part of the culture, economy and diet of coastal peoples for millennia. Historically, along the Pacific Coast, many tribes actively maintained "clam gardens" by moving rocks to create berms and terraces (Anderson and Parker 2009). Climate change threatens this resource in multiple ways including increases in surface temperatures, sea level rise and changes in ocean chemistry (e.g., temperature, $\mathrm{pH}$, dissolved oxygen, and nutrient concentrations) and circulation patterns (IPCC 2007a, b; NRC 2010b; Feely et al. 2012). These changes could affect every stage in the life cycles of shellfish and finfish.

Sea level rise will inundate existing shellfish beds. The intertidal ecosystem provides habitat, food, and refuge for hundreds of species, including forage fish, juvenile salmon, crab, eel grass, algae, clams and humans. Human response to storm damage (the manifestation of sea level rise) is typically to build more resilient infrastructure. This effectively cuts off the supply of sediments to beaches and prevents the shift of intertidal ecosystems landward - the natural response to sea level rise. In the conflict between allowing coastal habitat shift and maintaining space for land-based needs, the land-base needs often win. In more industrialized areas, sea level rise and storm surge may inundate sources of pollutants 
on land and wash them out to near shore areas, contaminating shellfish beds. Indeed, the National Oceanic and Atmospheric Administration's Damage Assessment, Remediation, and Restoration Program has created an online tool specifically geared towards incorporating interactive effects of climate change and contaminants in coastal protection and restoration in Puget Sound (Industrial Economics and Research Planning 2011).

Increasing air and water temperatures are also having negative impacts on marine life. Because warmer conditions affect mussels differently, warmer conditions over the past 50 years have led to a $51 \%$ decrease in the vertical extent of mussels along the Strait of Juan de Fuca and southern Vancouver Island, with populations disappearing entirely in the warmer parts of this region (Harley 2011). Warmer water temperatures are also creating conditions more favorable for the phytoplankton and bacteria that cause paralytic shellfish poisoning, amnesiac shellfish poisoning, and a range of other illnesses (Trainer et al. 2003).

Ocean acidification is a tremendous threat to aquatic ecosystems and the billions of people who rely on protein from the world's oceans. One of its many effects is to corrode the calcium carbonate shells of shellfish, a group that includes many of the species that form the base of the aquatic food chain (IPCC 2007b; Kleypas 2006; NRC 2010b; Feely et al. 2012). One-third of the carbon dioxide from anthropogenic sources is absorbed into the oceans (Sabine et al. 2004). This limits the rate of global climate change, but at the cost of altering the fundamental chemistry of the oceans (Orr et al. 2005; Kleypas et al. 2006; WA Blue Ribbon 2012).

\section{Tribal adaptation in a changing environment}

\subsection{Historic tribal approaches to adaptation}

Indigenous peoples have adapted to environmental conditions since time immemorial. Through observations of wildlife foraging and the harvesting and processing of foods, tribes refined their traditional ecological knowledge (TEK) of when, where, and how animals, plants, algae and fungi could be used as food. The extent of tribal TEK about different types of foods and corresponding ecosystems or habitats reflect millennia of experiences with changes in climate (Blukis Onat 2002; Huntington and Fox 2005). In this section, we explore how historic tribal adaptation to climate and ecosystem changes may inform tribal adaptation to climate change today. We also provide examples of contemporary tribal approaches to climate change adaptation.

Climate and ecosystems change over time. Paleoclimate, archaeology, and ethnoecological research provide a foundation for understanding how climate, environmental productivity and tribal food utilization strategies evolved. Historical evidence demonstrates the rate of climatic change experienced within past environments and the accompanying tribal food security systems that occurred in response to these changes (Moss et al. 2007). Although the rate of change experienced was not as rapid as contemporary conditions, tribes historically experienced significant climate changes that affected ecosystems (Moss et al. 2007) and food-based resources, requiring tribal cultures to strategically adapt and respond to survive (Meltzer 1999; Newsome et al. 2004).

Throughout these historic changes, indigenous peoples maintained access to many traditional foods. Tribal cultures developed sophisticated socio-economic and technological systems to access, acquire, process and store foods (Anderson and Parker 2009). In the Pacific Northwest, archaeological evidence suggests remarkably stable use of salmon over the past 7,500 years despite broad regional climatic stressors that reduced salmon populations and habitat quality (Campbell and Butler 2010). The key to this resilience is 
found in strong, multifaceted connections to the resources used, adaptive resource management, and beliefs and social institutions that kept salmon harvest within sustainable levels (Campbell and Butler 2010).

Traditional knowledge of ecological processes provides some insight into how climate change may impact traditional foods. However, limited access to the fraction of traditional territories, the competition tribes face when gathering, the ongoing impacts of colonization and urbanization, and the current state of environmental degradation pose significant threats to tribes' ability to maintain the progress they have made to maintain tribal health and traditional ways of life.

\subsection{Informing contemporary adaptation strategies}

Historic and cultural factors can inform how tribal adaptation to climate change may occur. Cultural attributes that aid tribes in adaptation include their relationship of respect and reciprocity that binds nature and harvester together as illustrated in the example of Wabanaki peoples and berry plants. As such, culture and TEK may guide the myriad of social, political, ecological and cultural adaptation strategies that tribes may pursue. Sociopolitical mechanisms include compelling federal agencies to clarify their legal obligations under the treaties and to implement those federal policies at the local level. Tribes may enter government-to-government agreements to increase their role in local resource management, to access additional areas to gather traditional foods, or lease and buy lands that ensure sustained access to traditional foods. Tribes may also exchange information and identify different technologies to access, acquire, process, and store foods. Additionally, tribes can develop formal and informal agreements with other tribes to grant or request access to traditional foods that may now only be found on one of their reservations. Tribes may have to consider diversifying their food-based resources and possibly adopting and utilizing new animals, plants, or fungi.

Addressing climate change through the knowledge, experiences, and policy contexts of indigenous peoples provides a powerful counter-point to the lack of effective global climate responses. As indigenous peoples may experience some of the harshest impacts of climate change, they can also lead the way in creative solutions for adaptation and ethical policy strategies. As part of the Arctic Climate Impact Assessment, the six permanent Arctic Indigenous peoples' organizations of the Arctic Council put forward a list of recommendations for the world to consider as part of our global response to climate change. These include, among other recommendations, bringing indigenous "views, perspectives, and recommendations to international institutions mandated to combat the impacts and effects of global climate change," and "acknowledging their authority to protect and promote their ways of life" (Watt-Cloutier et al. 2004). These suggestions clearly focus on more local approaches to climate change policy that treats indigenous peoples and TEK as not just data points to prove a larger trend, but as vital contributions to addressing climate change in an equitable manner.

A more localized example of tribal adaptation comes from the Confederated Tribes of the Umatilla Indian Reservation's (CTUIR) innovative partnership with local, state and federal entities. In 2006, in an effort to protect traditional foods (referred to as "First Foods" by the CTUIR), the CTUIR Department of Natural Resources adopted and implemented the First Foods mission. Based on the First Foods ceremonies and practices of the CTUIR, this mission provides an indigenous framework for restoring ecosystems that support culturally important foods. First Foods assessments are expected to inform future research questions, protection and restoration strategies, and policy development. Beyond restoring native 
habitats and protecting tribally-valued food resources, the mission also emphasizes the critical importance of tribal member access to their First Foods (Jones et al. 2008).

Also in the Pacific Northwest, tribes are working with government and nongovernmental organizations to restore access to and the habitat of tribally-valued food resources (Eckart 2012; White 2004). Changes in fire regimes, land management tenures, and public versus tribal values, have reduced access to and the quality of habitats that formally supported traditional foods. For example, in the Cascade Mountains of Oregon, the Confederated Tribes of Siletz Indians and the USDA Forest Service - Willamette National Forest are working together to enhance and restore huckleberries and camas roots. Hazardous fuels reduction and forest thinning treatments are being utilized to reduce tree competition and shading on huckleberries. Meadow restoration is facilitating access to and increases in the vigor of camas and other tribally-valued plants species, promoting tribal subsistence activities. These larger interconnected landscape forests and meadow treatments are thought to foster ecosystem resilience against the effects of detrimental wildfires and climate change (Paul 2010).

These examples demonstrate the ability of tribes to engage directly with federal partners to develop and implement adaptation strategies aimed at preserving tribal access to traditional foods.

\section{Conclusion}

Climate change impacts on tribal traditional foods should be viewed in the context of historical and cultural tribal relationships with places, wildlife, and plants, as well as in the landscape of the treaties, federal policies, and federal trust responsibilities and regulations in which they exist (Whyte 2013). Moreover, tribes view climate change adaptation in light of their reciprocal relations to care for and respect natural resources (Whyte 2013). As a result of these relationships of reciprocity and responsibility between tribes and nature and existing policies, Indian tribes' vulnerability to climate change, and the adaptation strategies they adopt are multi-faceted and deeply rooted in a complex historical context. As sovereign governments, tribes have the authority to identify and implement adaptation strategies, and attempt to influence and strengthen the climate change protocols of other governments.

The various adaptive practices tribal practitioners and communities employ may enable managers to institute changes in policies, regional strategies, and resource regulation/ conservation that enable ecosystems to respond more favorably to climate change. Tribal participation in local, regional and national climate change adaption frameworks and strategies, with a focus on food-based resources, can assist with prioritizing research and management directions.

Under extreme and rapid conditions of severe change at different ecological scales (AMS 2012), western scientists and managers may need to partner with tribal scientists, managers, harvesters, and communities to explore innovative approaches to addressing climate change impacts. Tribal participation in climate change research, policy development and planning can help identify more solutions that fully consider tribal cultural values. Climate change will not obey the jurisdictional boundaries between tribal, private, state, and federal lands. As such, meaningful government-togovernment relationships and collaboration will be vital to address the climate change impacts to the traditional foods, and to the wildlife, plants, and habitats valued by tribes and other Americans. 


\section{References}

American Meteorological Society (AMS) (2012) Climate change: An information statement of the American Meteorological Society. http://www.ametsoc.org/policy/2012climatechange.pdf. Accessed 4 Jan 2013

Anderson TL, Parker DP (2009) Economic development lessons from and for North American Indian economies. Aust J Agric Resour Econ 53:105-127. doi:10.1111/j.1467-8489.2007.00426.x

Basu A, Du M, Leyva MJ, Sanchez K, Betts NM, Wu M, Aston CE, Lyons TJ (2010) Blueberries decrease cardiovascular risk factors in obese men and women with metabolic syndrome. J Nutr 140:1582-1587. doi:10.3945/jn.110.124701

Beechie T, Imaki H, Greene J, Wade A, Wu H, Pess G, Roni P, Kimball J, Stanford J, Kiffney P, Mantua N (2012) Restoring salmon habitat for a changing climate. River Res Appl. doi:10.1002/rra.2590

Blukis Onat AR (2002) Resource cultivation on the northwest coast of North America. J Northwest Anthropol $36: 125-144$

Boyce VL, Swinburn BA (1993) The traditional Pima diet: composition and adaptation for use in a dietary intervention study. Diabetes Care 16:369-371. doi:10.2337/diacare.16.1.369

Burns Kraft TF, Dey M, Rogers RB, Ribnicky DM, Gipp DM, Cefalu WT, Raskin U, Lila MA (2008) Photochemical composition and metabolic performance-enhancing activity of dietary berries traditionally used by Native North Americans. J Agric Food Chem 56:654-660. doi:10.1021/jf071999d

Campbell SK, Butler VL (2010) Archaeological evidence for resilience of Pacific Northwest salmon populations and the socioecological system over the last 7,500 years. Ecol Soc 15:17

Center For Progressive Reform (CPR) (2011) Climate change and the Puget Sound: building the legal framework for adaptation. www.progressivereform.org/articles/Puget_Sound_Adaptation_1108.pdf. Accessed 14 Nov 2012

Colombi BJ (2009) Salmon nation: climate change and tribal sovereignty. In: Crate SA, Nuttall M (eds) Anthropology and climate change. Left Coast Press, Walnut Creek, pp 186-195

Conti KM (2006) Diabetes prevention in Indian country: developing models to tell the story of food-system change. J Transcult Nurs 17:234-245. doi:10.1177/1043659606288380

Cook K (1996) Using the berry plants for nutrition and medicine. Indigenous Women's Network. http:// www.indigenouspeople.net/berry.htm. Accessed 14 Oct 2012

Daigle JJ, Putnam D (2009) The meaning of a changed environment: initial assessment of climate change impacts in Maine - indigenous peoples. In: Jacobson GL, Fernandez IJ, Mayewski PA, Schmitt CV (eds) Maine's climate future: An initial assessment. University of Maine, Orono, pp 35-38

DeGonzague B, Receveur O, Wedll D, Kuhnlein HV (1999) Dietary intake and body mass index of adults in two Ojibwe communities. J Am Diet Assoc 99:710-716. doi:10.1016/S0002-8223(99)00170-4

Dittmer K (2013) Changing streamflow on columbia basin tribal lands-climate change and salmon. Clim Chang. doi:10.1007/s10584-013-0745-0

Eckart K (2012) Traditional foods help remind us who we are. Yes! Fall 2012 issue. http:// www.yesmagazine.org/issues/its-your-body/tribe-revives-traditional-diet. Accessed 14 Nov 2012

Feely RA, Klinger T, Newton JA, Chadsey M (2012) Scientific Summary of Ocean Acidification in Washington State Marine Waters. National Oceanic and Atmospheric Administration (NOAA) OAR Special Report

Frink DS, Dow J (2005) When the shad-blow blooms; an archaeology story. Burlington, VT: Unpublished Report

Grah O, Beaulieu J (2013) The effect of climate change on glacier ablation and baseflow support in the nooksack river basin and implications on pacific salmon species protection and recovery. Clim Chang. doi:10.1007/s10584-013-0747-y

Harley CDG (2011) Climate change, keystone predation, and biodiversity loss. Science 334:1124-1127. doi:10.1126/science. 1210199

Hoene N (2010) Climate change, an Ojibwe perspective. Seiche Newsletter. Minnesota Sea Grant Newsletter. March 2010. http://www.seagrant.umn.edu/newsletter/2010/03/climate_change_an_ojibwe_perspective.html. Accessed 19 Jan 2013

Hunn ES (1990) Nch'i-Wána, "The Big River": Mid-Columbia Indian and Their Land. University of Washington Press, Seattle and London, $378 \mathrm{p}$

Huntington HP, Fox S (2005) Chapter 3- The changing Arctic: Indigenous perspectives. In: Carolyn Symon (lead ed) Arctic Climate Impact Assessment (ACIA). Cambridge University Press, Cambridge pp 61-98

Industrial Economics Inc, Research Planning Inc (2011) Development and implementation of the climate assessment and proactive response initiative (CAPRI) for Puget Sound. Prepared for the National Oceanic and Atmospheric Administration (NOAA). http://www.darrp.noaa.gov/northwest/puget_sound/pdf/201111-03_DraftFinalCAPRI_NOAAWhitepaper.pdf. Accessed 14 Nov 2012 
Intergovernmental Panel on Climate Change (IPCC) (2007a) Summary for policymakers. In: Parry ML, Canziani OF, Palutikof JP, van der Linden PJ, Hanson CE (eds) Climate change 2007: Impacts, adaptation and vulnerability. Contribution of working group II to the fourth assessment report of the IPCC. Cambridge University Press, Cambridge, pp 7-22

Intergovernmental Panel on Climate Change (IPCC) (2007b) In: Solomon S, Qin D, Manning M, Chen Z, Marquis M, Averyt KB, Tignor M, Miller HL (eds) Climate change 2007: The physical science basis, Contributions of working group I to the fourth assessment report of the IPCC. Cambridge University Press, Cambridge, $996 \mathrm{p}$

Jernigan VBB, Salvatore AL, Styne DM, Winkleby M (2012) Addressing food insecurity in a Native American reservation using community-based participatory research. Health Educ Res 27:645-655. doi:10.1093/her/cyr089

Jones K, Poole G, Quaempts EJ, O’Daniel S, Beechie T (2008) Umatilla River Vision. http://www.ykfp.org/ $\operatorname{par10/html/CTUIRDNRUmatillaRiverVision100108.pdf.~Accessed~} 14$ Nov 2012

Kellogg J, Wang J, Flint C, Ribnicky D, Kuhn P, González de Mejia E, Raskin I, Lila MA (2010) Alaska wild berry resources and human health under the cloud of climate change. J Agric Food Chem 58:3884-3900. doi:10.1021/jf902693r

Kleypas JA, Feely RA, Fabry VJ, Langdon C, Sabine CL, Robbins LL (2006) Impacts of ocean acidification on coral reefs and other marine calcifiers: a guide for future research. Report of a workshop held 18-20 April 2005, St. Petersburg, FL, sponsored by NSF, NOAA, and the U.S. Geological Survey

Kocan RM, Hershberger PK, Winton JM (2004) Ichthyophoniasis: an emerging disease of chinook salmon, Oncorhynchus tshawytscha in the Yukon River. J Aquat Anim Health 16:58-72

Kuhnlein HV, Receveur O (1996) Dietary change and traditional food systems of indigenous peoples. Annu Rev Nutr 16:417-442. doi:10.1146/annurev.nu.16.070196.002221

Kuhnlein HV, Erasmus B, Spigelski D (2009) Indigenous peoples' food systems: the many dimensions of culture, diversity and environment for nutrition and health. United Nations Food and Agriculture Organization, Rome. http://www.fao.org/docrep/012/i0370e/i0370e00.htm. Accessed 19 Jan 2013

Lobell DB, Burke MB, Tebaldi C, Mastrandea MD, Falcon WP, Naylor RL (2008) Prioritizing climate change adaptation needs for food security in 2030. Science 319(5863):607-610. doi:10.1126/science.1152339

Maldonado JK, Shearer C, Bronen R, Peterson K, Lazrus H (2013) The impact of climate change on tribal communities in the US: displacement, relocation, and human rights. Clim Chang. doi:10.1007/s10584013-0746-z

Mantua N, Tohver I, Hamlet A (2010) Climate change impacts on streamflow extremes and summertime stream temperature and their possible consequences for freshwater salmon habitat in Washington State. Clim Chang 102:187-223. doi:10.1007/s10584-010-9845-2

McKay KL, Renk NF (2002) Currents and undercurrents: an administrative history of Lake Roosevelt National Recreation Area, Washington. Coulee Dam, Wash: U.S. Dept. of the Interior, National Park Service, Lake Roosevelt National Recreation Area

Meltzer DJ (1999) Human responses to middle Holocene (Altithermal) climates on the North America Great Plains. Quat Res 52:404-416

Michelle N (2012) Uses of plant food-medicines in the Wabanaki bioregions of the Northeast; a cultural assessment of berry harvesting practices and customs. University of Maine, Orono

Minnesota Department of Natural Resources (Minnesota) (2008) Natural wild rice in Minnesota. http:// files.dnr.state.mn.us/fish_wildlife/wildlife/shallowlakes/natural-wild-rice-in-minnesota.pdf. Accessed 14 Nov 2012

Moss ML, Peteet DM, Whitlock C (2007) Mid-Holocene culture and climate on the Northwest coast of North America. In: Anderson DG, Maasch K, Sandweiss DH (eds) Climate change and cultural dynamics: a global perspective on mid-Holocene transitions. Academic, London, pp 491-530

Mote PW, Parson EA, Hamlet AF, Keeton WS, Lettenmaier D, Mantua N, Miles EL, Peterson DW, Peterson DL, Slaughter R, Snover AK (2003) Preparing for climate change: the water, salmon, and forests of the Pacific Northwest. Clim Chang 61:45-88

Nabhan GP (2010) Perspectives in ethnobiology: ethnophenology and climate change. J Ethnobiol 30:1-4

National Research Council (NRC) (2010a) Advancing the science of climate change. The National Academies Press, Washington, DC

National Research Council (NRC), 2010b (2010b) Ocean acidification: a national strategy to meet the challenges of a changing ocean. The National Academies Press, Washington, DC

Newsome SD, Phillips DL, Culleton BJ, Guilderson TP, Koch PL (2004) Dietary reconstruction of an early to middle Holocene human population from central California coast: insights from advanced stable isotope mixing models. J Archaeol Sci 31:1101-1115. doi:10.1016/j.jas.2004.02.001 
Norgaard KM (2005) The effects of altered diet on the health of the Karuk people. http://karuk.us/press/2005/ Health Effects of Altered Diet.pdf. Accessed 14 Nov 2012

Norris T, Vines P, Hoeffel EM (2012) The American Indian and Alaska Native population: 2010. United States Census Bureau. http://www.census.gov/prod/cen2010/briefs/c2010br-10.pdf. Accessed 19 Jan 2013

Orr JC, Fabry VJ, Aumont O, Bopp L, Doney SC, Feely RA, Gnanadesikan A, Gruber N, Ishida A, Joos F, Key RM, Lindsay K, Maier-Reimer E, Matear R, Monfray P, Mouchet A, Najjar RG, Plattner GK, Rodgers KB, Sabine CL, Sarmiento JL, Schlitzer R, Slater RD, Totterdell IJ, Weirig MF, Yamanaka Y, Yool A (2005) Anthropogenic ocean acidification over the twenty-first century and its impact on calcifying organisms. Nature 437:681-686

Pacific Northwest Tribal Climate Change Project (PNW TCCP) (2012) First Foods and climate change. Pacific Northwest Tribal Climate Change Project profile. http://www4.nau.edu/tribalclimatechange/ tribes/tdk firstfoods.asp. Accessed 14 Nov 2012

Parrotta JA, Agnoletti M (2012) Traditional forest-related knowledge and climate change. In: Parrotta JA, Trosper RL (eds) Traditional forest-related knowledge: Sustaining communities, ecosystems and biocultural diversity. World Forests Volume 12. Springer, Dordrecht, pp 491-533

Paul A (2010) Forest Service wants to boost huckleberries. Albany Democrat-Herald Newspaper, 25 December 2010. http://democratherald.com/news/local/forest-service-wants-to-boost-huckleberries/article_ e2631f2c-0fe6-11e0-a692-001cc4c03286.html. Accessed 14 Nov 2012

Power EM (2008) Conceptualizing food security for aboriginal people in Canada. C J Public Health 99:95-98

Ravussin E, Valencia ME, Esparza J, Bennett PH, Schulz LO (1994) Effects of a traditional lifestyle on obesity in Pima Indians. Diabetes Care 17:1067-1074. doi:10.2337/diacare.17.9.1067

Redsteer MH, Kelley KB, Francis H, Block D (2010) Disaster risk assessment case study: recent drought on the Navajo nation, southwestern United States. UN Global Assessment Report 2011. http:// www.preventionweb.net/english/hyogo/gar/2011/en/bgdocs/Redsteer_Kelley_Francis_\&_Block_2010.pdf. Accessed 14 Nov 2012

Sabine CL, Feely RA, Gruber N, Key R, Lee K, Bullister JL, Wanninkhof R, Wong CS, Wallace DWR, Tilbrook B, Millero FJ, Peng TH, Kozyr A, Ono T, Rios AF (2004) The oceanic sink for anthropogenic $\mathrm{CO}^{2}$. Science 305:367-371. doi:10.1126/science. 1097403

Seeram NP (2008) Berry fruits: compositional elements, biochemical activities, and the impact of their intake on human health, performance, and disease. J Agric Food Chem 56:627-629. doi:10.1021/jf071988k

Teufel NI (1996) Nutrient-health associations in the historic and contemporary diets of Southwest Native Americans. J Nutr Environ Med 6:179-190. doi:10.3109/13590849609001044

Trainer VL, Eberhart BTL, Wekell JC, Adams NG, Hanson L, Cox F, Dowell J (2003) Paralytic shellfish toxins in Puget Sound, Washington State. J Shellfish Res 22:213-223

Verbrugge L (2010) Traditional foods in Alaska: potential threats from contaminants and climate change. State of Alaska Division of Public Health. Power Point Presentation. http://www.climatechange.alaska.gov/ docs/afe10/3_Verbrugge.pdf. Accessed 14 Nov 2012

Washington (WA) State Blue Ribbon Panel on Ocean Acidification (2012) Ocean acidification: from knowledge to action, Washington State's strategic response. Adelsman H, Whitely Binder L (eds) Washington Department of Ecology, Olympia, Washington. Publication no. 12-01-015. https:// fortress.wa.gov/ecy/publications/summarypages/1201015.html. Accessed 19 Jan 2013

Watt-Cloutier S, Fenge T, Crowley P (2004) Responding to global climate change: the perspective of the Inuit Circumpolar Conference on the Arctic Climate Impact Assessment. http://inuitcircumpolar.com/ index.php? $\mathrm{ID}=267$. Accessed 19 Jan 2013

White SM (2004) Bridging the worlds of fire managers and researchers: lessons and opportunities from the wildland fire workshops. USDA Forest Service, PNW-GTR-599

Whyte K (2013) Justice forward: tribes, climate adaptation and responsibility in indian country. Clim Chang. doi:10.1007/s10584-013-0743-2 